\title{
PENGARUH PERGANTIAN AUDITOR, UKURAN PERUSAHAAN, LABA RUGI DAN SOLVABILITAS TERHADAP AUDIT REPORT LAG (SEKTOR INDUSTRI DASAR KIMIA, BARANG KONSUMSI DAN ANEKA INDUSTRI)
}

\author{
Junri Eliangsor Situmeang, Wilisra Wilfrida Marbun, Risa Yunisa \\ Fakultas Ekonomi, Universitas Prima Indonesia \\ junri.situmeang09@gmail.com
}

\begin{abstract}
The Basic Industry and Chemicals, Consumer Goods, and Various Industries sectors are companies that are developing very rapidly and well. Audit report lag is the time span for completing an annual financial statement audit, measured by the number of days required to obtain an independent auditor's report on the audit. the company's annual financial statements. The method used in this research is a quantitative approach, the type of this research is descriptive research and the nature of this research is cause and effect research. The data collection method used is to use documentation techniques. The data analysis method used is logistic regression. The population is all companies listed on the Indonesia Stock Exchange in the Basic and Chemical Industry Sector, Consumer Products and Various Industries. Determination of the sample in this study by looking at whether companies in the population report financial statements that have been audited on time or not. The results on the hypothesis show that auditor turnover, firm size, profit and loss and solvency simultaneously have no effect on audit report lag. The conclusion of this study is that simultaneously and partially auditor turnover, firm size, profit and loss and solvency have no significant effect on audit report lag.
\end{abstract}

Keywords: auditor turnover, firm size, profit and loss, solvency, audit report lag.

\section{PENDAHULUAN}

Sektor industri dasar dan kimia,barang konsumsi dan aneka industri merupakan perusahaanperusahaan yang perkembangannya sangat pesat dan baik. Besarnya dana yang digelontarkan dalam pembangunan industri dasar dan kimia,barang komsumsi dan aneka industri menjadi indikator bahwa suatu negara sangat berdedikasi dalam memberikan fasilitas terbaik bagi warganya. Selain memiliki manfaat yang besar Industri dasar dan kimia,barang komsumsi dan Aneka Industri juga menjadi faktor penentu keberhasilan perekonomian di Indonesia. Pembangunan industry dasar dan Kimia ,barang komsumsi dan Aneka industi yang pesat dan berkembang dapat mendorong pemasukan negara dan mendukung pertumbuhan perekonomian di Indonesia.Industri dasar dan Kimia mengacu pada sistem fisik yang menyediakan bahan organik dan non organic mentah dengan proses kimia dan pembentukan produk yang dapat digunakan publik lain yang diperlukan untuk memenuhi kebutuhan dasar manusia secara ekonomi. Barang Komsumsi adalah produk akhir yang bisa dikomsumsi secara langsung oleh konsumen.

\section{KAJIAN LITERATUR}

Pergantian Auditor Berpengaruh pada Audit Report Lag 
Menurut Rustriani dan Sugiarti (2013) Apabila perusahaan mengalami pergantian auditor, tentunya auditor baru membutuhkan waktu yang cukup lama utuk mengenali karakteristik usaha klien dan sistem yang ada didalamnya sehingga hal ini menyita waktu auditor dalam melaksanakan proses aduitnya.

\section{Ukuran Perusahaan Berpengarauh pada Audit Report lag}

Menurut Suwito dan Herawaty (2005 : 138) Semakin besar ukuran satuan usaha maka struktur pengendalian internalnya juga semakin baik sehingga akan mengurangi kesalahan dalam penyajian laporan keuangan. Hal ini akan memudahkan pekerjaan auditor karena lingkup pengujian semakin sempit sehingga akan memperpendek audit delay.

\section{Laba Rugi Berpengaruh pada Audit Report Lag}

Menurut Kartika (2011 : 159-160) Auditor akan berhati-hati selama proses audit dalam merespon kerugian perusahaan apakah kerugian tersebut disebabkan oleh kegagalan finansial atau kecurangan manajemen. Jadi, semakin laba suatu operasi perusahaan, maka audit delaynya semakin pendek.

\section{Solvabilitas Berpengaruh pada Audit Report Lag}

Menurut Andi (2011: 160) Apabila proporsi hutang lebih besar dari aktivanya akan meningkatkan kecenderungan kerugian dan dapat meningkatkan kehati-hatian dari auditor terhadap laporan keuangan yang akan diaudit.

\section{Kerangka Konseptual}

Kerangka ini akan memperoleh hasil yang valid dan objektif.

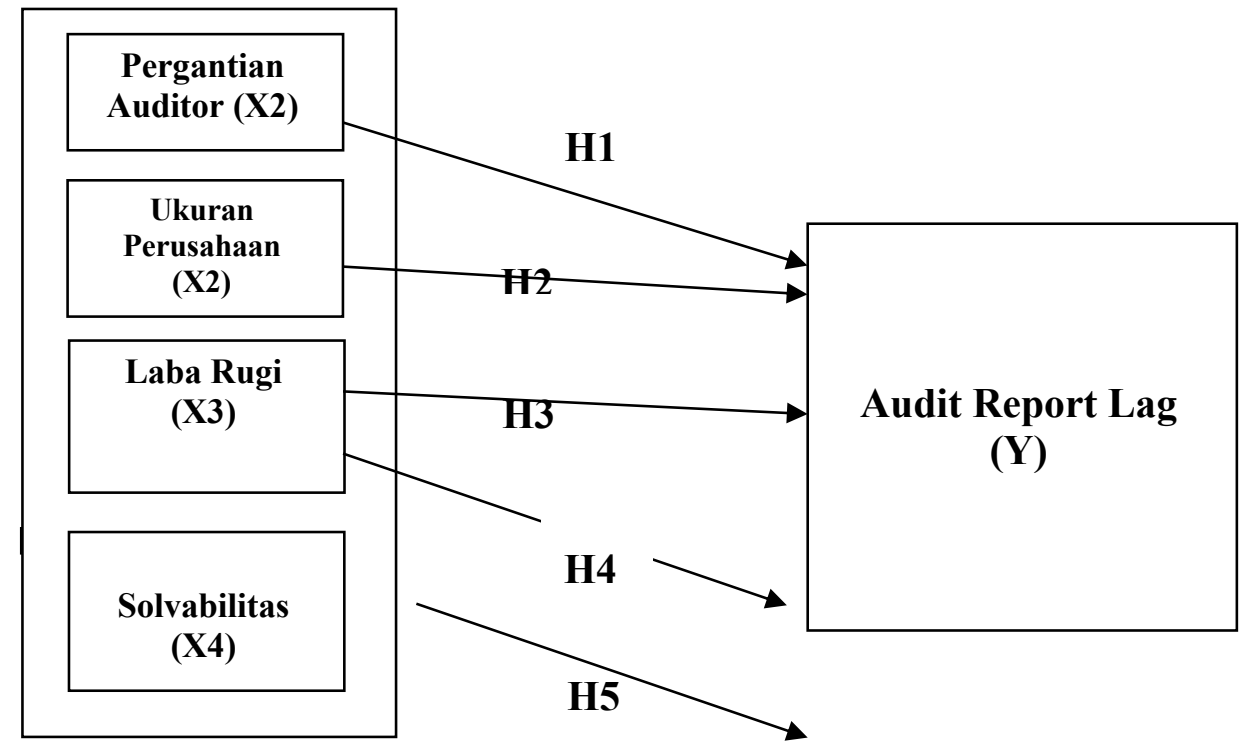

Hipotesis yang akan dibuktikan ada 5 yaitu:

H1 : Pergantian Auditor berpengaruh terhadap Audit Report Lag pada Sektor Industri Dasar dan Kimia,Barang Konsumsi,dan Aneka Inudstri Tahun 2017-2020 
H2 : Ukuran Perusahaan berpengaruh terhadap Audit Report Lag pada Sektor Industri Dasar dan Kimia,Barang Konsumsi,dan Aneka Industri Tahun 2017-2020.

H3 : Laba Rugi berpengaruh terhadap Audit Report Lag pada Sektor Industri Dasar dan Kimia,Barang Konsumsi,dan Aneka Industri Tahun 2017-2020.

H4 : Solvabilitas berpengaruh Secara Parsial terhadap Audit Report Lag pada Sektor Industri Dasar dan Kimia,Barang Konsumsi,dan Aneka Industi Taun 2017-2020

H5 : Pergantian Auditor, Ukuran Perusahaan, Laba Rugi dan Solvabilitas berpengaruh terhadap Audit Report Lag pada Sektor Indusri Dasar dan Kimia,Barang Konsumsi dan Aneka Industi Tahun 2017-2020 BAB II

\section{METODE}

Pendekatan penelitian yang digunakan dalam penelitian ini adalah pendekatan kuantitatif, Digunakan untuk meneliti pada populasi atau sampel tertentu, pengumpulan data menggunakan instrument penelitian, analasis data bersifat kuantitatif/Statistic

\section{Populasi Sample}

Populasi penelitian ini adalah 30 perusahaan sektor infrastruktur, utilitas dan transportasi. Berdasarkan dari populasi tersebut akan ditentukan sampel yang menjadi obyek penelitian ini. Teknik sampling yang digunakan adalah purposive sampling.Hipotesis penelitian diuji dengan menggunakan model regresi logistic dengan program software SPSS versi 16. Model persanab regresi yang digunakan adalah sebagai berikut :

\section{Koefisien Determinasi Hipotesis}

Cox dan Snell's $R$ Square merupakan ukuran yang mencoba meniru ukuran $\mathrm{R}^{2}$ pada multiple regression yang didasarkan pada teknik estimasi likelihood dengan nilai maksimum kurang dari 1 (satu) sehingga diinterprestasikan. Nagelkerke's R square merupakan modifikasi dari koefisien Cox dan Snell untuk memastikan bahwa nilainya bervariasi dari 0 (nol) sampai 1 (satu). Hal ini dilakukan dengan cara membagi Cox dan Snell's R Square dengan nilai maksimumnya. Nilai Nagelkerke's R Square dapat diinterprestasikan seperti nilai $\mathrm{R}^{2}$ pada multiple regression.

\section{Model Fit}

Statistik yang digunakan berdasarkan pada fungsi likelihood. Likelihood L dari model adalah probabilitas bahwa model yang dihipotesakan menggambarkan data input. Untuk menguji hipotesis nol dan alternative, L ditransformasikan menjadi -2 LogL.

\section{Pengujian Hipotesis Secara Simultan}

Uji Goodness of Fit Test digunakan untuk menguji kelayakan model agar penjelasan pengaruh dari seluruh variabel independent $\left(X_{1}, X_{2}, X_{3}, X_{4}\right.$, dan $\left.X_{n}\right)$ terhadap variabel dependent (Y) layak untuk dilakukan. Nilai G pada uji $\mathrm{G}$ adalah : 


$$
\mathrm{G}=-2 \ln \left[\frac{\text { Likelihood }(\text { Model B })}{\text { Likelihood }(\text { Model } A)}\right]
$$

Model B = Model yang hanya terdiri dari satu konstanta saja

Model A = Model yang terdiri dari seluruh variabel

Nilai G selanjutnya dibandingkan dengan nilai tabel khai kuadrat dengan kriteria pengambilan keputusan adalah :

$$
\begin{aligned}
& H_{0} \text { ditolak jika } \mathrm{G}>X_{\alpha . p}^{2} ; \alpha: 0,05, \text { sebaliknya } \\
& H_{0} \text { diterima jika } \mathrm{G}<X_{\alpha . p}^{2} ; \alpha: 0,05 .
\end{aligned}
$$

\section{HASIL DAN DISKUSI}

\section{Hasil Penelitian}

\section{Tabel 1. Statistik Deskriptif}

\begin{tabular}{|l|r|r|r|r|r|}
\hline \multicolumn{7}{|c|}{ Descriptive Statistics } \\
\hline & N & Minimum & Maximum & Mean & Std. Deviation \\
\hline Pergantian Auditor & 45 & 0 & 1 &, 13 &, 344 \\
Ukuran Perusahaaan & 45 & $1,34 \mathrm{E} 9$ & $1,09 \mathrm{E} 13$ & $1,066 \mathrm{E} 12$ & $2,22498 \mathrm{E} 12$ \\
Laba Rugi & 45 & $\ldots$ & $4,02 \mathrm{E} 11$ & $5,110 \mathrm{E} 10$ & $8,50272 \mathrm{E} 10$ \\
Solvabilitas & 45 & $1,96 \mathrm{E} 8$ & $6,10 \mathrm{E} 12$ & $5,137 \mathrm{E} 11$ & $1,15152 \mathrm{E} 12$ \\
AuditRenortLag & 45 & 0 & 1 & 53 &, 505 \\
Valid N (listwise) & 45 & & & & \\
\hline
\end{tabular}

Pada Tabel 1 dapat dijelaskan bahwaNilai minimum dari variabel Pergantian Auditor (X1) adalah 0, nilai maksimum dari variabel Pergantian Auditor (X1) adalah 1, nilai mean (rata-rata) dari variabel Pergantian Auditor (X1) adalah 0,13 dan standar deviasi dari Pergantian Auditor (X1) adalah 0,344.Nilai minimum dari variabel Ukuran Perusahaan (X2) adalah 1,34E9 pada Idocement Tunggal Perkasa Tbk, nilai maksimum dari variabel Ukuran Perusahaan (X2) adalah 1,09E13 pada PT Arwana Citramulia Tbk, nilai mean (rata-rata) dari variabel Ukuran Perusahaan (X2) adalah 1,066E12 dan standar deviasi dari variabel Ukuran Perusahaan (X2) adalah 2,22488E12,Nilai minimum dari variabel Laba-Rugi (X3) adalah... . pada Betonjaya Manunggal Tbk, nilai maksimum dari variabel Laba-Rugi (X3 adalah 4,02E11pada PT Arwana Citramulia Tbk, nilai mean (rata-rata) dari variabel Laba-Rugi (X3) adalah 5,710E10 dan standar deviasi dari variabel Laba-Rugi (X3) adalah 8,50272E10. Nilai minimum dari variabel Solvabilitas (X4) adalah 1,96E8 pada PT Barito Pasisic Tbk, nilai maksimum dari variabel Solvabilitas (X4) adalah 6,10e12 pada PT Arwana Citramulia Tbk, nilai mean (rata-rata) dari dari variabel Solvabilitas (X4) adalah5,137E11, dan standar deviasi dari variabel Solvabilitas (X4) adalah 1,15152E12.Nilai minimum dari variabel Audit Report Lag adalah 0, nilai maksimum dari variabel Audit Report Lag adalah 1, nilai mean (rata-rata) dari variabel Audit Report Lag adalah 0,53 dan standar deviasi dari variabel Audit Report Lag adalah 0,505 
Tabel 2.

\begin{tabular}{|c|c|c|c|c|}
\hline & Frequency & Percent & Vald Percent & $\begin{array}{l}\text { Cumulative } \\
\text { Percent }\end{array}$ \\
\hline Valid 0 & 39 & 86,7 & 86,7 & 86,7 \\
\hline 2017 & 6 & 13,3 & 13,3 & 100,0 \\
\hline Total & 45 & 1000 & 1000 & \\
\hline
\end{tabular}

Pada tabel 2 diatas, dapat dijelaskan bahwa total sampel penelitian adalah 15 perusahaan dikalikan selama 3 tahun dari tahun 2017-2020. Tabel diatas menunjukan bahwa ada 45 laporan perusahaan, 39 laporan perusahaan (86,7\%) yang tidak terjadi Pergantian Auditor dan sisanya sebanyak 6 laporan perusahaan $(13.3 \%)$ yang terjadi Pergantian Auditor.

Tabel 3.

Audit Report Lag

\begin{tabular}{|ll|r|r|r|r|}
\hline & & Frequency & Percent & Valid Percent & $\begin{array}{c}\text { Cumulative } \\
\text { Percent }\end{array}$ \\
\hline Valid & 0 & 21 & 46,7 & 46,7 & 46,7 \\
& 2017 & 24 & 53,3 & 53,3 & 100,0 \\
& Total & 45 & 100,0 & 100,0 & \\
\hline
\end{tabular}

Pada Tabel 3 diatas menunjukan bahwa total sampel penelitian adalah 15 perusahaan selama 3 tahun yaitu dari tahun 2017-2020. Tabel diatas menunjukan bahwa ada 45 laporan perusahaan, 21 laporan perusahaan (46,7\%) melaporkan laporan keuangan tidak tepat waktu dan sisanya sebanyak 24 laporan perusahaan $(53.3 \%)$ melaporkan laporan keuangan tepat waktu.

\section{Menguji Kelayakan Model Regresi (Goodness of Fit Test)}

Untuk menilai kelayakan model regresi yang digunakan dapat dilihat dari nilai Hosmer and Lemeshow Test, seperti yang disajikan pada tabel dibawah ini. 
Tabel 4.

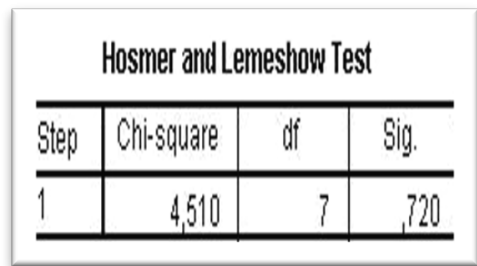

Pada Tabel 4,uji Hosmer and Lemeshow Test menunjukan bahwa besarnya nilai Chi-Square sebesar 4,510 dengan nilai signifikan sebesar $0,720(0,0720>0,05)$, dimana H1 diterima dan dapat disimpulkan bahwa nilai Hosmer and Lemeshow Goodness of Fit Test Statistics lebih besar dari 0,05, maka observasi pada Goodness Fit Model baik, karena model dapat memprediksi sudah memenuhi kecukupan data.

\section{Menguji Keseluruhan Model Fit (Overall Model Fit Test)}

Uji asumsi klasik yang dilakukan dalam penelitian ini adalah menguji apakah model regresi yang dibuat adalah model fit dengan data penelitian. Statistik yang digunakan berdasarkan fungsi likelihood. Pengujian ini dilakukan dengan melihat nilai -2LL pertama dengan -2 LL kedua pada tabel iteration history pada hasil penelitian. Tabel dibawah akan menunjukkan hasil dari -2 log likelihood pertama pada block number $=0$ dan hasil dari $-2 \log$ likehood kedua pada block number $=1$, adalah sebagai berikut :

Nilai -2 log likelihood (-2 LL, Block Number = 0)

Tabel 5.

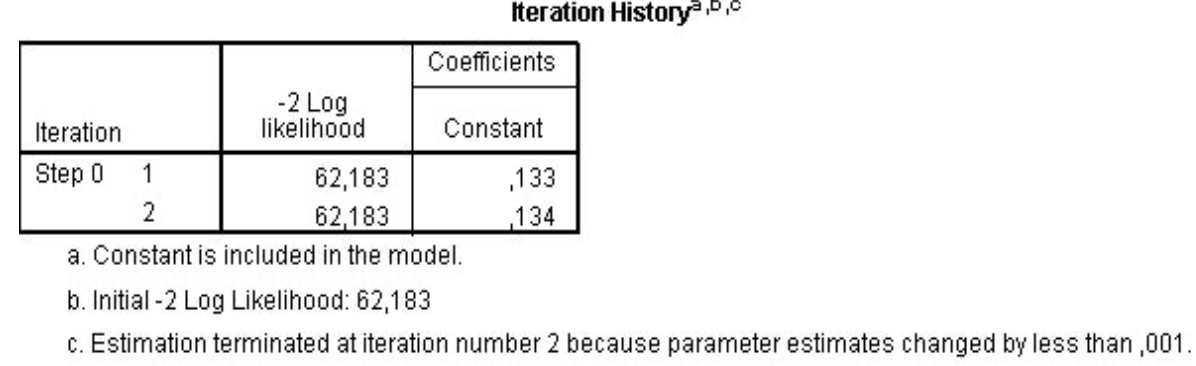

Nilai -2 log likelihood (-2 LL, Block Number =1)

Tabel 6.

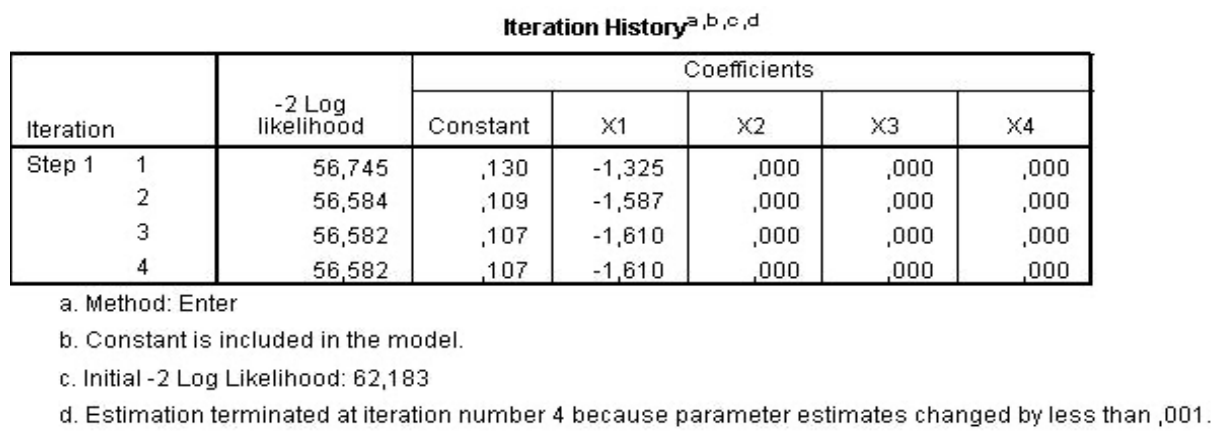


Pada tabel 6 diatas menunjukan bahwa nilai -2 log likelihood yang terdiri dari konstanta saja tanpa adanya variabel bebas, sementara pada tabel IV.8 menunjukan bahwa nilai -2 log likelihood yang terdiri dari konstanta dan variabel bebas. Nilai -2 log likelihood yang hanya memasukkan konstanta saja adalah sebesar 62,183. Sedangkan nilai -2 log likelihood yang memasukkan konstanra dan variabel bebas adalah sebesar 56,745. Model ini menunjukkan adanya penurunan Overall Model Fit pada -2 log likelihood block number $=0$ ke -2 log likelihood block number $=1$ sebesar 5,438. Penurunan likelihood menunjukan secara keseluruhan model yang baik, dimana penurunan nilai -2 log likelihood menunjukkan bahwa model penelitian ini dinyatakan fit. Artinya, penurunan likelihood ini menunjukkan model regresi yang lebih baik atau dengan kata lain model dihipotesiskan fit dengan data.

\section{Uji Koefisien Determinasi (Nagelkerke's R Square)}

Koefisien determinasi pada dasarnya digunakan untuk mengukur seberapa jauh kemampuan model dalam menerangkan variansi variabel dependen yang akan diteliti.

Nilai koefisien determinasi yang kecil menandakan kemampuan variabel-variabel independen dalam menjelaskan variabel dependen sangatlah terbatas. Nilai koefisien determinasi yang mendekati satu, berarti variabel-variabel independen hampir dapat memberikan semua informasi yang dibutuhkan untuk memprediksi variabel dependen.

Tabel 7. Koefisien Deteminasi

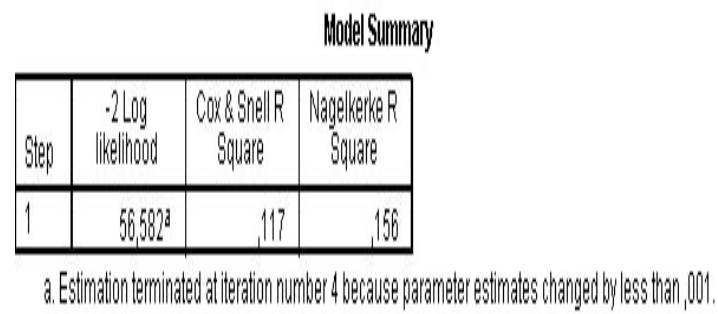

Tabel 7 untuk menunjukkan sebesar besar variabel independen mampu menjelaskan dan mempengaruhi variabel dependen. Nilai Nagelkerke's $R$ Square pada tabel diatas sebesar 0.156 atau 15,6\%. Hal ini berarti kemampuan variabel dependent dalam penelitian dapat dijelaskan oleh variabel independen yang diteliti dalam penelitian dapat dijelaskan oleh variabel dependen yang diteliti dalam penelitian ini sebesar $15,6 \%$, sisanya $85,4 \%$ dapat dijelaskan oleh variabel lain yang tidak termaksud dalam penelitian ini seperti Ukuran KAP, Jenis Industri, Profitabilitas, Gender Auditor dan Reputasi KAP.

Tabel 8. Omnibus Test of Model Coefficient

Omnibus Tests of hodel Coefficients

\begin{tabular}{|ll|r|r|r|}
\hline & & Chi-square & df & Sig. \\
\hline Step 1 & Step & 5,601 & 4 &, 231 \\
& Block & 5,601 & 4 &, 231 \\
& Model & 5,601 & 4 & 231 \\
\hline
\end{tabular}

Dari Tabel 8, sesuai dengan pengujian regresi logistik diketahui bahwa nilai Chi-Square sebesar 5,601 dengan degree of freedom adalah 4 . Adapun tingkat signifikansi sebesar 0,231 yang nilainya $>0,05$, maka 
H5 ditolak yang berarti Pergantian Auditor, Ukuran Perusahaan, Laba Rugi dan Solvabilitas secara simultan tidak berpengaruh signifikan terhadap Audit Report Lag

\section{Pengujian Individual / Pengujian Koefisien Regresi}

Untuk menentukan hasil akhir dari penelitian dan menjawab hipotesis yang disusun sebelumnya, digunakan tabel variables in the equation yang ada pada output hasil pengolahan data yang disajikan pada tabel 9 sebagai berikut:

Tabel 9.

Variables in the Equation

\begin{tabular}{|c|c|c|c|c|c|c|c|c|c|}
\hline & \multirow[b]{2}{*}{ B } & \multirow[b]{2}{*}{ S.E. } & \multirow[b]{2}{*}{ Wald } & \multirow[b]{2}{*}{ df } & \multirow[b]{2}{*}{ Sig. } & \multirow[b]{2}{*}{$\operatorname{Exp}(B)$} & \multicolumn{2}{|c|}{$95,0 \%$ c.lfor EXP(B) } \\
\hline & & & & & & & & Lower & Upper \\
\hline \multirow[t]{5}{*}{ Step $1^{\mathrm{a}}$} & $x_{1}$ & $-1,610$ & 1,078 & 2,230 & 1 & ,135 & 200 &, 024 & 1,654 \\
\hline & $x_{2}$ & ,000 & ,000 & .617 & 1 & .432 & 1,000 & 1,000 & 1,000 \\
\hline & $\times 3$ &, 000 & ,000 & 2,698 & 1 &, 100 & 1,000 & 1,000 & 1,000 \\
\hline & $\times 4$ &, 000 &, 000 & 1,901 & 1 & 168 & 1,000 & 1,000 & 1,000 \\
\hline & Constant & 107 & 402 & 071 & 1 & 790 & 1,113 & & \\
\hline
\end{tabular}

a. Variable(s) entered on step $1: X_{1}, X_{2}, X_{3} \times 4$.

Pada Tabel 9 diatas menunjukkan hasil pengujian secara parsial sebagai berikut :

H1 : Pengaruh Pergantian Auditor terhadap Audit Report Lag.Hasil analisis data penelitian yang ditunjukkan oleh tabel variabel in the equation pada kolom sig memberikan hasil signifikansi $0,135>$ 0,05 .

H2 : Pengaruh Ukuran Perusahaan terhadap Audit Report Lag.Hasil analisis data penelitian yang ditunjukkan oleh tabel variabel in the equation pada kolom sig memberikan hasil signifikansi 0,432.

H3 : Pengaruh Laba Rugi terhadap Audit Report Lag.Hasil analisis data penelitian yang ditunjukkan oleh tabel variabel in the equation pada kolom sig memberikan hasil signifikansi 0,100.

H4 : Pengaruh Solvabilitas terhadap Audit Report Lag.Hasil analisis data penelitian yang ditunjukkan oleh tabel variabel in the equation pada kolom sig memberikan hasil signifikansi 0,168 . .

\section{Pembahasan Diskusi}

\section{Pengaruh Pergantian Auditor Terhadap Audit Report Lag}

Hasil penelitian peneliti menunjukan bahwa variabel Pergantian Auditor tidak berpengaruh secara signifikan terhadap Audit Report Lag. Hal ini dapat dilihat dari uji hipotesis dimana nilai signifikansi Pergantian Auditor 0,135 lebih besar jika dibanding dengan taraf signifikansi 5\% $(0,135>0,05)$. 


\section{Pengaruh Ukuran Perusahaan Terhadap Audit Report Lag}

Hasil penelitian peneliti menunjukkan bahwa variabel Ukuran Perusahaa tidak berpengaruh secara signifikan terhadap Audit Report Lag. Hasil ini dapat dilihat dari hasil uji hiporesis dimana nilai signifikansi Ukuran Perusahaan 0,432dimana lebih besar jika dibandingkan dengan taraf signifikansi 5\% $(0,432>0,05$.

\section{Pengaruh Laba Rugi Terhadap Audit Report Lag}

Hasil penelitian peneliti menunjukkan bahwa variabel Laba Rugi tidak berpengaruh secara signifikan terhadap Audit Report lag. Hasil ini dapat dilihat dari hasil uji hipotesis dimana nilai signifikansi Laba Rugi 0,100 dimana lebih besar jika dibandingkan dengan taraf signifikansi 5\% $(0,100>0,05)$

\section{Pengaruh Solvabilitas Terhadap Audit Report Lag}

Hasil penelitian peneliti menunjukkan bahwa variabel Solvabilitas tidak berpengaruh secara signifikan terhadap Audit Report Lag. Hasil ini dapat dilihat dari hasil uji hipotesis dimana nilai signifikansi Solvabilitas 0,168, dimana lebih besar jika dibandingkan dengan taraf signifikansi 5\% $(0,168>0,05)$.

\section{KESIMPULAN}

Hasil Penelitian ini dapat disimpulkan yaitu Ukuran Perusahaan tidak berpengaruh secara signifikan terhadap Audit Report Lag. Laba Rugi tidak berpengaruh secara signifikan terhadap Audit Report Lag. Solvabilitas tidak berpengaruh secara signifikan terhadap Audit Report. Pergantian Auditor, Ukuran Perusahaan, Laba Rugi dan Solvabilitas tidak berpengaruh terhadap Audit Report Lag dengan nilai koefisien determinasi sebesar $15.6 \%$. Peneliti selanjutnya mampu menambah tahun periode, mensubsitusi variabel independent dengan variabel lain yang tidak termasuk di dalam penelitian ini. Bagi perusahaan sektor Industri Dasar dan Kimia,Barang Konsumsi dan Aneka Industi diharapkan dapat dijadikan bahan pertimbangan dalam merumuskan kebijakan mengenai laporan keuangan perusahaan. Bagi Investor memberikan informasi tentang pengaruh pergantian auditor, ukuran perusahaan, laba rugi dan jenis perusahaan terhadap audit report lag. sehingga dapat menjadi bahan pertimbangan dan pengambilan keputusan investasinya.

\section{REFRENSI}

Abdullah, M. Faisal, 2005. Dasar-dasar Manajemen Keuangan. Edisi Kedua, Cetakan Kelima, Penerbitan Universitas Muhammadiyah, Malang.

Asnawi, Said Kelana dan Chandra Wijaya. 2010. Pengantar Valuasi. Jakarta: Salemba Empat.

Boynton, William C.et.al. 2003. Modern Auditing. Edisi Ketujuh, Jakarta : Erlangga.

Budiasih, Igan. 2009. "Faktor - Faktor yang Mempengaruhi Praktik Perataan Laba". Jurnal Akuntansi Bisnis, Vol. 4 No. 1. Januari.hal: 44- 50.

Dwiyanti, Sabeni. 2014. “Faktor-faktor yang mempengaruhi Auditor Switching Secara Voluntary". Jurnal Fakultas Ekonomi Universitas Gunadarma.

Febrianty, 2011. "Faktor-faktor yang berpengaruh terhadap audit Delay perusahaan sektor perdagangan yang Terdaftar di BEI periode 2007- 2009". Jurnal Ekonomi Dan Informasi Akuntansi (Jenius), VOL. 1 No. 3 September 2011

Ghozali, Imam.2016. Aplikasi Analisis Multivariete dengan Program IBM SPSS23. Semarang: Badan Penerbit Universitas Diponegoro.

Halim, Varianada.2000. "Faktor-Faktor Yang Mempengaruhi Audit Delay". Jurnal Bisnis dan Akuntansi, Vol. 2, No. 1, pp 63-75. 
Harahap, Sofyan Syafri.2007.Teori Akuntansi.Jakarta: Raja Grafindo Persada.

Hariani, Diana dan Darsono, 2014."Faktor-Faktor Pemengaruh Audit Report Lag (Studi Empiris pada Perusahaan-Perusahaan di Bursa Efek Indonesia)". Diponegoro Journal of Accounting, Vol.3,No.2,Tahun 2014,Halaman 1.

Hery. 2015. Analisis Laporan Keuangan. Yogyakarta: CAPS.

Hery.2011. Auditing I: Dasar-dasar Pemeriksaan Akuntansi. Jakarta: Kencana.

Horne, James C. Van dan John M Wachowicz, Jr. 2012. Prinsip-prinsip Manajemen Keuangan (Edisi 13). Jakarta : Salemba Empat.

Ikatan Akuntan Indonesia, 2007. Standar Akuntansi Keuangan. Salemba Empat, Jakarta.

Ikatan Akuntan Indonesia. 2014. StandarAkuntansiKeuangan. Jakarta: Grha Akuntan.

Iskandar, Meylisa Januar dan Trisnawati Estralita, 2010. "Faktor-Faktor yang Mempengaruhi Audit Report Lag pada Perusahaan yang Terdaftar di Bursa Efek Indonesia". Jurnal Bisnis dan Akuntansi.

Jumingan, 2006. Analisis Laporan Keuangan. Cetakan Pertama, PT Bumi Aksara, Jakarta.

Kamaludin, dan Rini Indriani. 2012. Manajemen Keuangan Edisi Revisi. Cetakan Kedua. Bandung : CV Mandar Maju.

Kartika, Andi, 2011. "Faktor-Faktor Yang Mempengaruhi Audit Delay Pada Perusahaan Manufaktur Yang Terdaftar Di BEI'. Dinamika Keuangan dan Perbankan, Vol. 3 No. 2

Kasmir. 2012. Analisi Laporan Keuangan. PT.Raja Grafindo Persada, Jakarta.

M. Fuad, et. al.2005. Pengantar Bisnis.Ed.4.Jakarta: Gramedia Pustaka Utama.

Marathani, Dhea Tiza.2013. "Faktor-faktor yang Mempengaruhi Ketepatan Waktu Penyampaian Laporan Keuangan (Studi Empiris Pada Perusahaan Manufaktur yang Terdaftar di Bursa Efek Indonesia tahun 2010-2012”. Fakultas Ekonomi dan Bisnis Universitas Brawijaya.

Mulyadi. 2002. Auditing. Buku 1 Edisi Keenam, Cetakan ke- 1, Jakarta : Salemba Empat.

Munawir, S, 2007. Analisis Laporan Keuanngan. Penerbit Liberty, Yogyakarta.

Pawitri, Ni Made Puspa dan Ketut Yadnyana. 2015. "Pengaruh Audit Delay, Opini Audit, Reputasi Auditor dan Pergantian Manajemen pada Voluntary Auditor Switching”. E-jurnal Akuntansi Universitas Udayana. ISSN: 2302- 8578.

Prayogi, 2012. "Faktor-Faktor yang Berpengaruh Terhadap Audit Delay (Studi Empiris pada Perusahaan Telekomunikasi yang Terdaftar di Bursa Efek Indonesia pada Tahun 2009-2011)".

Rahayu, Siti Kurnia. \& Suhayati Ely. 2013. Auditing (Konsep Dasar dan Pedoman dan Pemeriksaan Akuntansi Publik). Edisi Pertama Cetakan ke- 2, Jakarta : Graha Ilmu,.

Ratnawati dan Sugiharto. 2005. Audit delay pada industry real estate dan property yang terdaftar di Bursa Efek Jakarta dan faktor yang mempengaruhinya. Seminar Nasional. PESAT

Rochimawati, 2008. "Analisis Diskriminan Audit Delay Pada Industri Keuangan di Bursa Efek Indonesia (BEI)". Jurnal Akuntansi dan Keuangan, Volume. 14 Nomor.2.

Rodoni, Ahmad, dan Herni Ali. 2014. Manajemen Keuangan Modern. Cetakan Pertama. Jakarta : Mitra Wacana Media.

Rustriarini, Mita Sugiarti. 2013. "Pengaruh Karakteristik Auditor, Opini Audit, Audit Tenure, Pergantian Auditor" pada Audit Delay. Jurnal Ilmiah Akuntansi dan Humanika JINAH Universitas Mahasaraswati Denpasar.

Santoso, Iman. 2007. "Akuntansi Keuangan Menengah (Intermediate Accounting) Buku Satu. Bandung : PT. Refika Aditama.

Sanusi Anwar.2011. Metodologi Penelitian Bisnis. Cetakan keempat, Jakarta: Salemba Empat.

Setyawan, Angga. 2016. Analisis Faktor-Faktor Yang Mempengaruhi Audit Delay (Studi Empiris pada perusahaan Aneka Industri dan Keuangan di BEI Tahun 2012-2014). Skripsi. Fakultas Ekonomi dan Bisnis Universitas Muhammadiyah Surakarta, Jawa Tengah.

Simbolon, Kartika. 2009. "Analisis Faktor-Faktor Yang Mempengaruhi Audit Delay Pada Perusahaan Yang Terdaftar di Bursa Efek Indonesia".

Sitanggang, J.P. 2013. Manajemen Keuangan Perusahaan Lanjutan Dilengkapi soal dan Penyelesaiannya. Edisi I. Jakarta: Mitra Wacana Media. 
Sjahrial, Dermawan dan Djahotman Purba. 2013. Analisis Laporan Keuangan. Jakarta: Mitra Wacana Media.

Soetedjo, Soegeng, 2006. “Faktor-Faktor Yang Mempengaruhi Audit Delay Log (ARL)". Vol 9 No. 2. Agustus. pp $77-92$.

Subekti, Imam dan Novi Wulandari Widiyanti.2004."Faktor-Faktor Yang Berpengaruh Terhadap Audit Delay Di Indonesia". SNA VII Denpasar Bali. Pp 991-1002.

Sugiyono. 2012. Metode Penelitian Bisnis. Cetakan Keenam Belas, Bandung: Alfabeta.

Sulistyo, Wahyu Adhy Noor. 2010. Analisis Faktor-faktor yang Berpengaruh Terhadap Ketepatan Waktu Penyampaian Laporan Keuangan Pada Perusahaan yang Listing di Bursa Efek Indonesia Periode 2006-2008. Fakultas Ekonomi Universitas Diponegoro.

Sunyoto, Danang, 2013. Metode Penelitian Akuntansi. PT Refika Aditama, Bandung.

Suwardjono. 2014. Teori Akuntansi Perekayasaan Pelaporan Keuangan. Edisi Ketiga, Cetakan Kedelapan. Yogyakarta: BPFE.

Suwito, Edy, dan Arleen Herawaty, 2005, "Analisis pengaruh karakteristik perusahaan terhadap tindakan perataan laba yang dilakukan oleh perusahaan yang terdaftar di BEJ', SNA VIII, Solo.

Syafri Harahap, Sofyan, 2015. Analisa Kritis atas Laporan Keuangan. PT. Raja Grafindo Persada, Jakarta.

Walsh, Ciaran, 2004. Key Management Ratios Rasio-rasio Manajemen Penting Penggerak dan Pengendali Bisnis. Edisi 3, Erlangga, Jakarta.

Warren, Reeve \& Fees, 2005. Prisnsip-Prinsip Akuntansi. Buku Satu, Edisi Kedua Puluh Satu, 